Article

\title{
Determinants of Adoption of Multiple Climate-Smart Adaptation Practices in Sudano-Sahelian Pastoral and Agro-Pastoral Production Systems
}

\author{
Nouhoun Zampaligré ${ }^{1,2, *}$ and Lisa Elena Fuchs ${ }^{3}$ (D) \\ 1 Institut de l'Environnement et de Recherches Agricoles (INERA), Station Farako Bâ, 01 BP: 910 Bobo \\ Dioulasso, Burkina Faso \\ 2 Centre International de Recherche-Développement sur l'Elevage en zone Subhumide (CIRDES), \\ 01 BP: 454 Bobo Dioulasso 01, Burkina Faso \\ 3 Systems Theme, World Agroforestry Centre (ICRAF), P.O. Box 30677, 00100 Nairobi, Kenya \\ * Correspondence: nouhoun.zampaligre@cirdes.org
}

Received: 11 May 2019; Accepted: 19 July 2019; Published: 4 September 2019

\begin{abstract}
To improve their ability to plan for and respond to potential negative impacts of climate shocks, such as droughts and dry spells, in the Sahelian agricultural production systems, many farmers have adopted diversified coping and adaptation strategies to secure their livelihoods. However, the scientific understanding of the key factors that determine the decisions that these pastoralist and agro-pastoralist households make, as well as the relation between existing human, social, natural, physical and financial assets and the adoption of adaptation practices at the household level has remained insufficient. Therefore, multivariate probit estimates were used to identify the key drivers of multiple adoption of climate-smart agro-pastoral adaptation practices in the Sudano-Sahelian zone of Burkina Faso. The results indicated that respondent households adopted a combination of adaptation practices rather than a single practice. Most of these practices aimed at enhancing household food security and livelihoods. Regarding the variables that are related to the adoption of these adaptation practices overall, a few assets were found to contribute significantly to the decision to adopt the assessed adaption practices. These include the possession of household and farm assets and equipment, membership in associations and assistance from government, farming experience of the household head, access to credit, as well as ownership and size of farmland. In addition, access to climate and agronomic information, as well as a household's location within a specifically dedicated pastoral zone, enhanced uptake of various adaptation practices in this study. Access to these assets and features hence plays a critical role in pastoralists' and agro-pastoralists' adaptive capacity. This study provides insights for policy makers in view of climate change adaptation and wider sustainable development planning in the Sudano-Sahelian zone of Africa.
\end{abstract}

Keywords: adaptive capacity; climate-smart technologies; climate change adaptation; agro-pastoralism; MVP

\section{Introduction}

In Burkina Faso, as in many sub-Saharan countries, agricultural production, including livestock production, is the main source of income for rural households. However, agricultural production systems depend on climate conditions and are likely to be affected by the adverse effects of climate change and variability. Most of the farming households in Burkina Faso are highly vulnerable to such change and variability because of both the climate sensitivity of livelihood strategies and the overall scarcity of resources [1]. Water availability is increasingly sporadic, leading to Burkina Faso experiencing either drought or quasi-drought conditions for the majority of the year. These episodes of drought threaten agricultural production and subsistence livelihoods and hence strongly impact 
the country's population. Over time, households have developed adaptation strategies in order to mitigate the potential and actual impact of climate shocks, and/or cope with their adverse effects. Some of these household adaptation strategies were inventoried, documented and classified as 'best climate adaptation strategies in the Sahel and Burkina Faso' [2,3]. Included in these lists are water and soil management practices, such as stone bunds and Zai, as well as soil fertility management practices including composting, alongside a number of agroforestry practices, all of which are commonly referred to as climate-smart agricultural strategies in the literature [4-6]. A majority of these strategies are yield productivity-enhancing technologies that are geared towards improving food security. The adoption of these climate-smart technologies can contribute to strengthen farmers' food security, their ability to deal with climate change and variability, as well as their overall welfare. However, the uptake of these practices depends on farmers' capacity and incentives to make adjustment in their farming, and thus on their adaptive capacity [7]. It is largely acknowledged that adaptive capacity is critical in the design and implementation of effective adaptive strategies to reduce vulnerability of socio-ecological systems to climate change [8]. Climate change and variability impacts can hence be disproportionate across and within households due to differences in adaptive capacity. A households' adaptive capacity is influenced by various attributes such as governance, knowledge/information, support for innovations, and institutional capacity at the system level, as well as by household-level capacity to anticipate and respond to shocks. This latter component is based on households' access to or ownership of assets that include human, social, financial, natural and physical capitals, as outlined in the sustainable livelihoods framework (SLF) [9].

Numerous studies quantitatively analysed the determinants of adoption of adaptive strategies in the agricultural sector at the household level [4,5,10-13]. Ahmed [10] in southern Nigeria and Coulibaly et al. [14] in Malawi, for instance, showed that access and ownership of key household capitals (human, social, financial, natural and physical) affect adaptive capacity and vulnerability of farming households, and therefore influence their choices of adaptive options and practices to cope with climatic and environmental risks. These studies also showed that adaptation to climate change is a complex process that, beyond a household's asset base, involves other key features of the respective socio-ecological systems, including perception of climate change and variability, governance and access to information.

This study contributes to this growing literature by focusing more comprehensively on the household-level and system-level capacities that influence adaptation to climate change. In particular, this study examines the key household assets, access to climatic and agronomic information and the specific location of a household in view of households' ability to adopt a number of adaptation practices in central-southern region of Burkina Faso. The findings from this study are aimed at informing policies and programs to reduce vulnerability to climate variability and extremes, and to contribute positively to food security in pastoral and agro-pastoral production systems in the Sudano-Sahelian zone of Burkina Faso.

\section{Materials and Methods}

\subsection{Study Area Description}

The study area covers the pastoral zone of Sondré-Est and its surrounding villages (Figure 1). The pastoral zone of Sondré-Est is a territory of 16,460 ha that was set aside as a specifically dedicated livestock production zone in 1977. Pastoralists originating from the northern territories of the country have obtained pieces of land and settled in and around the pastoral zone since that time. The zone is composed of four residential sectors and is part of the administrative jurisdiction of Bindé municipality of the Centre Sud region of Burkina Faso. It is mainly inhabited by Fulani pastoralists while the surrounding villages are dominated by members of the Mossi and Bissa ethnic groups. Some Fulani pastoralists are also found in these villages. The main production system in the pastoral zone is livestock rearing, while crop production remains marginal. In the surrounding villages, livelihoods are 
typically more diversified and combine subsistence crop production, livestock rearing, petty trade and other off-farm activities. Livestock species reared are cattle, sheep and goats. Main food crops cultivated are sorghum, millet, rice and maize, while cotton, cowpea and groundnuts are cultivated as cash crops. For the purpose of this study, only those households that self-identified as either pastoralist or agro-pastoralist households were considered, while specialised crop famers' data were not included in the analysis.

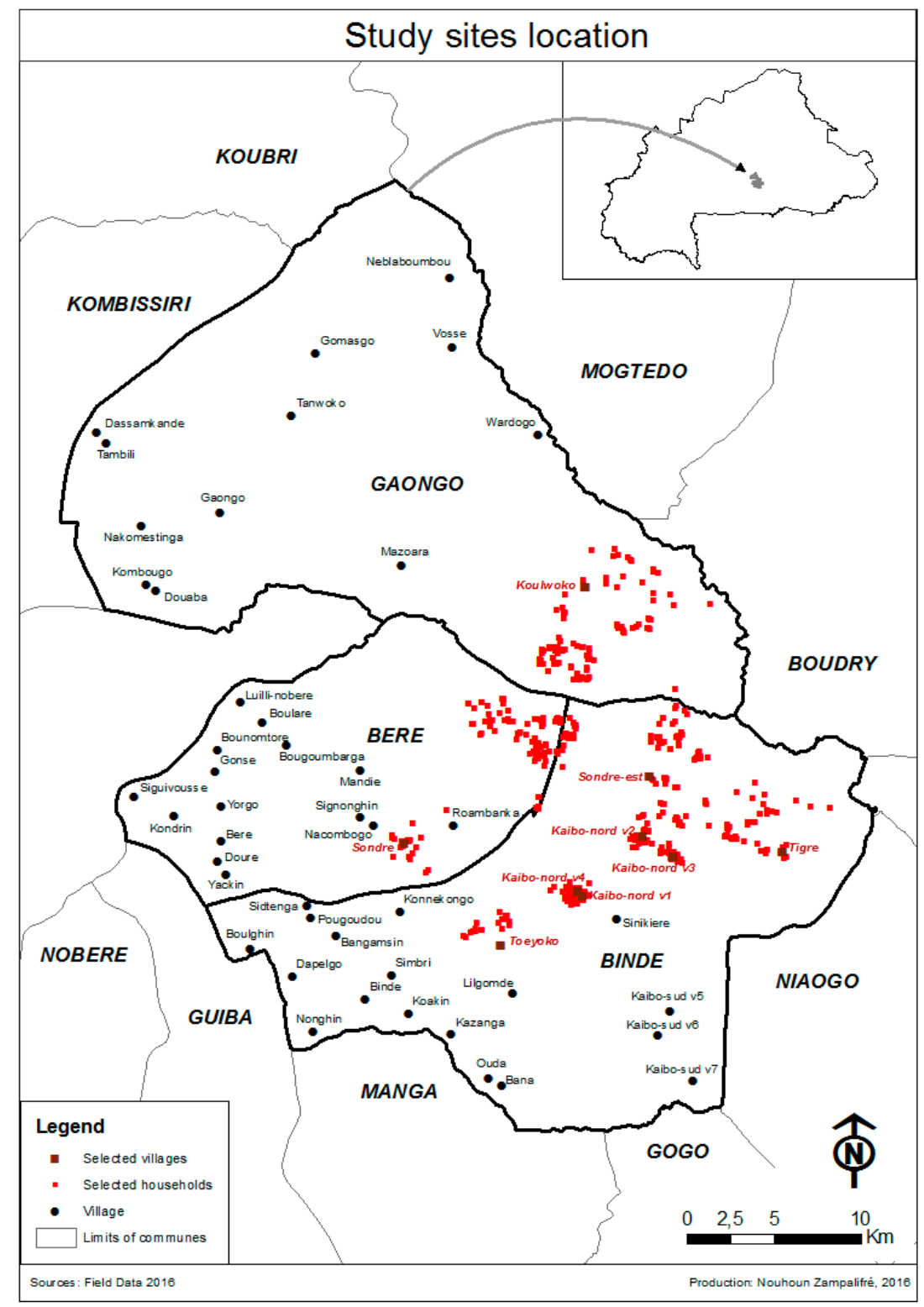

Figure 1. Study site locations and households interviewed.

The study area is located in the Sudano-Sahelian climate zone, the biggest of the three climatic zones in Burkina Faso, whose climate is characterized by an alternation of one dry season (November-May) and one rainy season (June-October). The average annual precipitation varies between $600-900 \mathrm{~mm}$ with high spatial-temporal variation. Temperature also varies depending on the month and the season of the year. The average temperature is $28^{\circ} \mathrm{C}$. The study area is crossed by several important rivers including the Nakambé (Red Volta) and several small seasonal feeder rivers. The vegetation is typical North Sudanian vegetation shaped by a combination of climatic factors and anthropogenic influences. It is dominated by wooded and shrub savannah, as well as gallery forests along rivers and water bodies. 
The flora is composed of Anogeisus leocarpa, Acacia sp., Balanites aegyptiaca and Piliostigma reticulatum and Piliostigma. thoningui trees and shrub species, alongside annual or perennial grasses such Andropogon gayanus, Pennisetum pedicelatum, etc. [15].

\subsection{Household Sampling and Data Collection Procedures}

To identify respondent households, we used stratified purposive sampling. First, the pastoral zone of Sondré-Est and its surrounding villages were selected purposively. Then, in each of these areas, two distinct groups of households were identified and randomly selected based on their primary livelihood activity (pastoralist and agro-pastoralist). A sample of 500 households was targeted to allow for statistical relevance. Regarding the survey, a structured questionnaire was administered to the selected household respondents. Prior to the household survey, focus-group discussions were held to obtain qualitative information about production systems and livelihood activities and strategies. Separate focus group discussions were held with pastoralists, agro-pastoralists and government extension service agents. While all focus group discussions involved men and women of different ages, the survey was targeted at the head of each respondent household. Before conducting the survey, the questionnaire was pre-tested with ten households. The survey was carried out between 28 March and 15 April 2016 using the ODK platform, a free and open-source set of tools which help organizations, author, field, and manage mobile data collection solutions (https://opendatakit.org/).

\subsection{Econometric Model and Variables Description}

\section{Analytical Framework: Multivariate Probit Analyses (MVP)}

To assess the key drivers of farmers' decision to jointly adopt a mix of prominent adaptation practices in their crop and livestock production systems, we used an MVP econometric model. Generally, farmers are likely to adopt a mix of strategies to deal with a multitude of agricultural production constraints rather than adopting a single coping or adaptation technology [16]. Since farmers in the pastoral and agro-pastoral systems in the Sahel are involved in crop and livestock production, they typically adopt and engage in adaptation practices related to both production systems concurrently. Therefore, a univariate modelling procedure to identify determinants of adoption would not be appropriate. A multivariate model, on the other hand, considers interactions and possible simultaneity in the adoption of different practices. As the MVP simultaneously models the relationships between a set of explanatory variables and adopted adaptation practices, it allows us to understand the potential correlation between unobserved disturbances, as well as between the different practices [17]. This empirical approach was successfully used by several studies to assess determinants of adoption of climate change adaptation practices in the agricultural sector [18-20]. The MVP model for this study is characterized by a set of $m$ binary dependent variables $Y_{h j}$ such that:

$$
\begin{gathered}
Y_{h j}^{*}=X_{h j}^{\prime} \beta j+u_{h j} \text { and } \\
Y_{h j}=1, \text { if } Y_{h j}^{*}>0 \text { and } 0 \text { otherwise }
\end{gathered}
$$

where $j=1,2 \ldots m$ denotes the type of adaptation strategy available; $X_{h j}^{\prime}$ is a vector of explanatory variables, $\beta_{j}$ denotes the vector of parameters to be estimated, and $u_{h j}$ are random error terms distributed as multivariate normal distribution with zero mean and unitary variance. It is assumed that a rational $h^{\text {th }}$ farmer has a latent variable $Y^{*}{ }_{h j}$ which captures the unobserved preferences or demand associated with the $j^{\text {th }}$ choice of adaptation strategy.

Engagement in several prominent climate-smart adaptation practices were used as dependent variables. The climate change adaptation literature for the agricultural sector in the West African Sahel region inventoried and described numerous adaption practices and strategies [6,12,13,21]. In this study, we focussed on seven practices that were described and assessed as good and innovative practices in crop and livestock production systems in the Sahelian countries, and which are currently being 
promoted by government and NGOs in the region as climate-smart technologies [2,3]. These practices target both crop and livestock production and aim at enhancing household food security and livelihoods. These household-level adaptation strategies include innovative practices that are either 'endogenous', described as either locally-derived or traditional, or 'exogenous', derived from sources outside of the respective 'local' settings [22] (see Table 1).

Table 1. List of dependent variables used in the MVP model.

\begin{tabular}{cl}
\hline \multicolumn{1}{c}{ Practices } & Description and Rational \\
\hline & Intensive zero-grazing livestock production practice that relies on industrial livestock \\
& feed including cotton seed cake or crop residues (cereals and legumes), locally called \\
& SPAI (sous-produits agro-industriels). This practice is increasingly adopted by settled \\
pastoralists and agro-pastoralists to adjust to reduced pasture and water availability \\
during the dry season. Zero-grazing using SPAI allows to appropriately feed livestock \\
during the dry season, and to earn an extra income from livestock sales. Since it \\
proposes an alternative to on-farm grazing of crop residues, it also helps to prevent \\
farmer-herder conflicts because it reduces the necessity for cattle to enter \\
agriculturalists' farms to feed on crop residues.
\end{tabular}

Cultivation of double-purpose crop species (fodder and food crops), cultivation of grass species, as well as hay production from natural occurring pasture and rangelands that can be used to feed livestock during the dry season when pastures and rangeland Fodder and forage production forage are dry and of low nutritional value. This practice has become prominent due to decreased natural fodder availability under climate variability and change. It is promoted by government extension services and NGOs that provide training, as well as production and storage equipment and materials to both pastoralist and agro-pastoralist households.

Seasonal and cyclical migration of herders and their livestock (mainly cattle and sheep) over long distances across regions, countries and agro-ecologies to seek better grazing areas and water resources. This practice plays an important role in feeding livestock during the dry season and during drought periods. While transhumance is a key

Transhumance feature of pastoral production systems in general, which provides pastoralists access to complementary pastoral resources across the major agro-ecological zones in West Africa (from the arid/semi-arid to the sub/humid zones), it also helps them to cope with climate variability and droughts and thus qualifies as a climate change adaptation strategy [3].

Production and use of organic matter extracted from crop residues, livestock manure and other household residues, typically to fertilize soils. Composting is typically more widely practiced by crop farmers and agro-pastoralists than by pastoralists to improve soil fertility and improve crop production. When combined with other soil and water conservation techniques, it can improve crop yields and provide economic benefits to farmers [6].

Composting

Use of drought-tolerant and high-yielding crop varieties that are adapted to specific agro-ecological zones. If used appropriately, these crop varieties contribute to increase crop yields and to reduce crop failure caused by droughts and dry spells. Most of the improved seed varieties in Burkina Faso are selected by the Institut de l'Environnement et de Recherches Agricoles (INERA) crop breeding programs. Improved varieties are mainly used in sorghum, millet, cow pea and maize production.

Use of improved crop varieties

Well-known soil and water conservation technique that is endogenous to the Sahel. Stone bunds are used along contour lines to slow down, filter and spread out runoff Stone bunds water, thus increasing infiltration and reducing soil erosion. Similar to Zai and half-moon practices, farmers use stone bunds to restore and manage the fertility of their soils in Sahelian countries such as Mali, Niger and Burkina Faso [23].

Farmer's protection and preservation of trees or shrubs, as well as tree and shrub seedlings, on their farms to promote regeneration of degraded soils and to create multiple-use agroforestry systems. If well established and properly managed, FMNR can provide multiple services and goods to farmers including food, firewood and shade, and can contribute to improved crop yields, animal productivity, and

Farmer-managed natural regeneration (FMNR) biodiversity on farm [24].

Various household assets, climate and weather forecast, agronomic information and location were used as explanatory variables (see Table 2 for the list and description of explanatory variables used in the MVP model). 
In the context of this study, "assets" were defined as being synonymous to "resources" or "capitals" in a broad sense; i.e., something that can be used to provide a livelihood. A livelihood comprises the capabilities, assets (including both material and immaterial resources) and activities required for a means of living. A livelihood is sustainable when it can cope with and recover from stresses and shocks, maintain or enhance its capabilities and assets, while not undermining the natural resource base [9]. The five key capitals, as described in the SLF [9], are physical capital (including infrastructure for shelter, energy and water supply, for transport and communications, and for production), human capital (including good health, the ability to work, as well as skills and knowledge), natural capital (including natural resources of land, water, etc.), financial capital (including savings, credit, remittances, pensions), and social capital (including relationships and networks with other people). In our study, the different capitals were operationalised as follows:

Human capital was represented by the household head's age and level of education, as well as by the total number of household members. The education level is assumed to provide basic information on an individual's or a household's ability to understand technical aspects of climate change information and agricultural technologies [11,18], which can improve decision-making to adopt appropriate adaptation strategies and technologies [18,19]. The household head's age was used as a proxy for farming experience and knowledge on climate change, as it is assumed that older farmers have experienced past and present weather conditions and that they adjusted their farming systems to cope with observed climate change and its impacts on their farming and livestock husbandry $[13,15]$.

Financial capital was represented by livestock ownership and access to credit. Livestock ownership can be used as a proxy for financial assets because, in addition to its multiple socio-economic and cultural roles, livestock plays an important financial role in rural areas of developing countries due to persistent absence of credit and financial markets. Indeed, livestock (small and large ruminants as well as poultry) is perceived as a savings account or as insurance, which can provide cash and smoothen consumption in times of need. Beyond livestock, access to credit can potentially facilitate the adoption of new technologies because it allows farmers to overcome situations in which lack of income and/or cash flow hinder such [19]. Overall, it is also assumed that higher income enables households to absorb and to recover from climate losses and damages quicker than those with lower income levels [25].

Social capital was represented by access to government assistance, as well as membership in farmers' groups. Assistance from government, in terms of access to free extension services and training, for instance, can enable farmers to have better knowledge and information on weather conditions, appropriate management practices and can potentially provide them access to training on new agricultural practices. Farmers with assistance have better chances to cope with climate risks by using appropriate technologies [18]. Membership in famers' groups can help farmers to be socially connected and can increase chances of accessing information and other extension services that are essential for their livelihood activities.

Physical capital was represented by a household asset index that was used as proxy to capture household physical assets. The asset index was constructed, using principal component analyses (PCA). The index constructed encompasses ownership of household equipment such as radio, TV, cell phone, bicycle, motorbike, as well as farm equipment such as, cart, water pump, ox plough, and access to road infrastructure.

Natural capital was represented by access to key natural resources, as well as the size of land held for crop and livestock production. Since land is the main natural resources on which pastoral and agro-pastoral production systems are based, both for grazing animals and for crop production, access to and ownership of land can contribute to the adoption of sustainable adaptation practices [18]. 
Table 2. Description and descriptive statistics of the explanatory variables used in the MVP model.

\begin{tabular}{|c|c|c|c|}
\hline Types of Assets & Mean & SE & Description of the Adaptation Options \\
\hline \multicolumn{4}{|l|}{ Human assets } \\
\hline Education HH head (continuous) & 0.49 & 0.082 & Number of years of formal education attained by the household head (continuous) \\
\hline Age HH head (continuous) & 44.35 & 0.618 & Age of the household head \\
\hline Total number of HH members (continuous) & 9.75 & 0.239 & Total number of household members \\
\hline \multicolumn{4}{|l|}{ Natural assets } \\
\hline Access to grassland (dummy) & 0.99 & 0.038 & During the last rainy season, did your household experience problems accessing the grassland? $($ Yes $=1$ and No $=0)$ \\
\hline Access to crop residues (dummy) & 0.31 & 0.036 & During the last rainy season, did your household experience problems accessing the crop residues? (Yes $=1$ and No $=0$ ) \\
\hline Size of land held (continuous) & 4.38 & 0.102 & What is the size (ha) of land owned by the household? \\
\hline \multicolumn{4}{|l|}{ Social assets } \\
\hline Assistance from government (dummy) & 0.06 & 0.011 & Did the household get any money, food or any type of assistance from the government? $($ Yes $=1$ and $\mathrm{No}=0)$ \\
\hline Member of association (dummy) & 0.53 & 0.022 & Are you a member of an association, cooperative, community group in the village? (Yes $=1$ and No $=0)$ \\
\hline \multicolumn{4}{|l|}{ Physical assets } \\
\hline HH asset index (continuous) & $3.54 \times 10^{-8}$ & 0.087 & Aggregate index that encompasses ownership of household and farm equipment \\
\hline \multicolumn{4}{|l|}{ Financial assets } \\
\hline Access to credit (dummy) & 0.42 & 0.022 & Do you or does a member of your household have access to credit (formal or informal) in the village? $($ Yes $=1$ and $N o=0$ ) \\
\hline Large livestock owned less than 50 (dummy) & 0.72 & 0.020 & Is your cattle herd number year around less than $50 ?(\mathrm{Yes}=1$ and $\mathrm{No}=0)$ \\
\hline Large livestock owned 50 to 100 (dummy) & 0.21 & 0.018 & Is your cattle herd number year around between 50 and $100 ?($ Yes $=1$ and $\mathrm{No}=0)$ \\
\hline Large livestock owned more than 100 (dummy) & 0.05 & 0.010 & Is your cattle herd number year around between 100 and 150 ? If yes $=1$, otherwise, no $=0$ \\
\hline Ruminants owned less than 50 (dummy) & 0.67 & 0.021 & Is your small ruminant (sheep and goat) herd number year around less than 50 ? (Yes $=1$ and $\mathrm{No}=0$ ) \\
\hline Ruminants owned more than 100 (dummy) & 0.05 & 0.011 & Is your small ruminant (sheep and goat) herd number year around between 100 and $150 ?($ Yes $=1$ and No $=0)$ \\
\hline \multicolumn{4}{|l|}{ Access to climate and agronomic information } \\
\hline Access to climate info for grazing (dummy) & 0.64 & 0.021 & Do you have access to seasonal climate information to decide where to graze to graze your animals? (Yes $=1$ and $\mathrm{No}=0$ ) \\
\hline Access to pasture availability info (dummy) & 0.72 & 0.021 & Do you have access to information on pasture availability to decide where to go with your animals? (Yes $=1$ and No $=0$ ) \\
\hline Access to water point availability info (dummy) & 0.69 & 0.021 & Do you have access to information on water point availability to decide where to go with your animals? (Yes $=1$ and $\mathrm{No}=0$ ) \\
\hline Access to climate info for cropping (dummy) & 0.50 & 0.023 & Do you have access to climate information to decide which farm technology to use? (Yes =1 and No $=0$ ) \\
\hline Access to agronomic info for cropping (dummy) & 0.49 & 0.023 & Do you have access to agronomic information to decide which farm technology or adaptation option to use? ( $Y e s=1$ and No $=0$ ) \\
\hline \multicolumn{4}{|l|}{ Location in the pastoral zone } \\
\hline Location within pastoral zone (dummy) & 0.51 & 0.022 & Is your household located in the pastoral zone of Sondré-Est? $($ Yes $=1$ and $\mathrm{No}=0)$ \\
\hline
\end{tabular}


Climate forecast and agronomic information: Climate information, operationalised as having access to weather forecasts, and other climate-related agronomic information, can be important for farmers' decision-making about adjustments to their farming systems and activities to respond to the possible damage of climatic risks [26]. Availability of and access to such information can lead to increased uptake of suitable adaptation strategies and practices at household level, and to the rejection of unsuitable ones [18].

Location in, or being an inhabitant of, the pastoral zone: Since the pastoral zone, by definition, was primarily dedicated to pastoral livestock production, it only allowed for small-scale subsistence crop production. Most of the inhabitants were settled pastoralists and agro-pastoralists whose livelihoods primarily depended on pastoral livestock rearing. Due to the land use restrictions within the pastoral zone, as well as the differences in historicity of residents in and outside of the zone, location was expected to influence the kind and combination of practices adopted.

Study limitations: Language, overall, was a complicated factor in the study. Since the original questionnaire was designed in French, all indicators and practices needed to be translated into local languages. To enable the enumerators to use local languages during the interviews, they were trained extensively and pre-tested the questionnaire in the field to further refine translations and explanations. Another limitation to the study was that it exclusively focussed on interviewing household heads, which were almost exclusively male. Deliberately questioning female participants, either within the same household or in separate households, could have provided further insights and a gendered perspective in term of adoption of adaptation practices and strategies.

\section{Results and Discussion}

\subsection{Socio-Economic Characteristics of Sampled Households}

Respondent households were exclusively male-headed. Only $7.37 \%$ of household heads had primary or secondary school education level, while the others did not receive any formal schooling $(90.85 \%)$. Regarding their primary livelihood, $62.6 \%$ of respondents indicated being settled pastoralists, whose livelihoods predominantly depended on livestock production, while $37.4 \%$ self-identified as agro-pastoralists, whose livelihoods draw on both the livestock and the crop system. Most respondents were migrants who were settled in the study area through the AVV (Aménagement des Vallées de la Volta) program in the 1990s. The average household size was 10 persons per family. The mean farm size was 2.28 ha, with livestock herd sizes being mostly between 50 to 100 heads of cattle $(93.25 \%)$ and the same number of small ruminants $(92.65 \%)$. Pastoralist households had smaller crop farm areas, ranging from 0.5 to $1.5 \mathrm{ha}$, while the agro-pastoralists had much larger crop farm areas ( 3.5 to $7 \mathrm{ha}$ ). Concerning livestock husbandry, the main species kept were cattle, goats, sheep and poultry. Large herds were owned by pastoralists, while agro-pastoralists mostly had smaller herd sizes, typically ranging from 0 to 50 heads of livestock. Both pastoralist and agro-pastoralist households were engaged in crop and livestock farming as livelihood activities but the degree and importance of both differed. Settled pastoralists in the pastoral zone owned land for the production of both food and fodder crops, but they continued to practice their pastoral livestock husbandry system. The latter included a feeding system based on rangelands and little use of agricultural by-products, as well as active transhumance southward during dry seasons and drought years. A majority of agro-pastoralists in the study area were former specialized crop farmers that currently engaged in livestock keeping with small to large herds, in addition to using animals to plough their farms. Since the great drought in the Sahel region in the 1970s, agro-pastoralism, and hence a mixed crop-livestock system, has increasingly been considered as a more sustainable livelihood strategy than specialized crop farming in the Sahel region due to its multiple benefits for soil fertility management, animal power of ploughing, and use of crop residues as livestock feeds. Adoption of agro-pastoralism itself can thus be described as adaptation strategy. 


\subsection{Household-Level Adoption of Innovative and Climate-Smart Adaptation Practices}

Table 3 presents the percentage of households that indicated having adopted the selected climate-smart adaptation practices in the study area. It differentiates between the total sample and the sub-samples that were disaggregated according to the respondent households' main livelihood activity. Adoption rates for all the practices among the total sample ranged from $21.27 \%$ for the production and use of compost as organic manure to $56.86 \%$ for transhumance. Adoption rates for practices such as the use of stone bunds or compost were significantly higher among agro-pastoralist households, while fodder and forage production and transhumance were more common among pastoralist households. This indicates that agro-pastoralists were more likely to adopt innovative practices related to the crop production system, while pastoralist households were more interested in adaptation practices related to the livestock production system. Some practices, however, including zero-grazing, use of improved crop varieties, and application of FMNR, were adopted by similar proportions among both livelihood groups $(p \geq 0.05)$.

Table 3. Adoption of the key adaptation practices among the sampled household in the study area.

\begin{tabular}{ccccc}
\hline $\begin{array}{c}\text { Production } \\
\text { System }\end{array}$ & Practice & $\begin{array}{c}\text { All Households } \\
(\mathbf{n}=\mathbf{5 0 2})\end{array}$ & $\begin{array}{c}\text { Pastoralists } \\
(\mathbf{n}=\mathbf{3 6 6})\end{array}$ & $\begin{array}{c}\text { Agro-Pastoralists } \\
\text { (n = 133) }\end{array}$ \\
\hline \multirow{2}{*}{ Cropping } & Stone bunds & 23.26 & 8.89 & 47.34 \\
& Composting & 21.27 & 5.71 & 47.34 \\
& Improved crop varieties & 40.36 & 36.51 & 46.81 \\
\hline \multirow{2}{*}{ Livestock } & Transhumance & 56.86 & 77.46 & 22.34 \\
& Fodder production & 23.06 & 33.33 & 5.85 \\
& Zero-grazing system & 27.44 & 20.95 & 38.3 \\
\hline Agroforestry & FMNR & 46.32 & 46.35 & 46.28 \\
\hline
\end{tabular}

\subsection{Determinants of Adoption of Multiple Climate Smart Adaptation Practices}

\subsubsection{Relationship between the Engagement in Different Climate-Smart Adaptation Practices}

As expected, respondents engaged in various adaptation practices in combination. The pair-wise correlation coefficient of the MVP estimates used to test the relationship between the different adaptation practices indicated that the MVP model was appropriate as it rejected the null hypothesis (Log likelihood $=-1555.24$, Prob $>$ chi $2=0.001$ ).

The results (see Table 4) showed a positive and significant correlation between the use of compost, stone bunds, improved crop varieties and FMRN, meaning that those practices were complementary and were used simultaneous. A similar positive and significant relationship was found for the combination of improved crop varieties, FMNR, fodder and forage production, and livestock fattening (zero-grazing). Practices such as the use of compost, stone bunds and FMNR aim at managing soil fertility and water conservation through the introduction of organic matter (compost), by slowing down runoff and soil degradation (stone bunds), and by promoting vegetation cover (FMNR) on farm. When used in combination with improved crop varieties, the adoption of these practices is likely to improve farm productivity, increase crop production and provide economic benefits [6]. Positive livelihood outcomes can also be expected for the combined adoption of improved crop varieties, fodder and forage production and zero-grazing. Since some improved crops varieties are dual purpose (forage and grain), adoption of such seeds can provide the fodder required for fattening livestock. These observed combinations have become common in agro-pastoral zones across Burkina Faso, where crop residues play a great role in filling dry season feed gaps for livestock, while manure is used for compost to fertilize the soils. On the other hand, a significant negative correlation was found between composting and fodder production, as well as between fodder production and transhumance, which means that respondents did not adopt them in combination, and that they might be antagonistic. 
Table 4. Correlation matrix of the dependent variables used in the Multivariate Probit analysis.

\begin{tabular}{|c|c|c|c|c|c|c|c|}
\hline $\begin{array}{l}\text { Adaptation } \\
\text { Options }\end{array}$ & Compost & $\begin{array}{l}\text { Stones } \\
\text { Bunds }\end{array}$ & $\begin{array}{l}\text { Improved } \\
\text { Seed }\end{array}$ & FMNR & $\begin{array}{l}\text { Forage and } \\
\text { Fodder }\end{array}$ & Zero-Grazing & Trans-Humance \\
\hline Compost & 1 & & & & & & \\
\hline Stones bunds & $0.265^{* * *}$ & 1 & & & & & \\
\hline Improved seed & $0.156^{* * *}$ & $0.083 *$ & 1 & & & & \\
\hline FMNR & 0.081 * & $0.148^{* * *}$ & $0.202 * *$ & 1 & & & \\
\hline Forage and fodder & $-0.193^{* * *}$ & $-0.090^{* *}$ & $0.184^{* * *}$ & $0.153^{* * *}$ & 1 & & \\
\hline Zero-grazing & $0.192^{* * *}$ & $0.157^{* * *}$ & $0.211^{* * *}$ & $0.080 *$ & 0.065 & 1 & \\
\hline Transhumance & $-0.351^{* * *}$ & $-0.308^{* * *}$ & -0.018 & -0.026 & $0.145^{* * *}$ & $-0.102 * *$ & 1 \\
\hline $\mathrm{Nb}$ of Observations & \multicolumn{7}{|c|}{499} \\
\hline Wald chi2 (154) & \multicolumn{7}{|c|}{753.95} \\
\hline Log likelihood & \multicolumn{7}{|c|}{-1555.2384} \\
\hline Prob $>$ chi2 & \multicolumn{7}{|c|}{0.0000} \\
\hline
\end{tabular}

Significance levels: ${ }^{*}, * * * * *$ Significant at 10,5 and $1 \%$, respectively.

\subsubsection{Key Determinants of the Engagement in Multiple Adaptation Practices}

Several factors in this study were found to show a significant correlation with the engagement in at least one adaptation practice (Table 5). Since the aim of this study was to identify those that influence farmers' decision to uptake or engage in multiple adaptation practices in combination, we focused the discussion on the factors that were significantly correlated to engagement in at least three adaptation practices (Table 6).

Table 5. Multivariate Probit estimates on the adoption of innovative and climate smart adaptation practices.

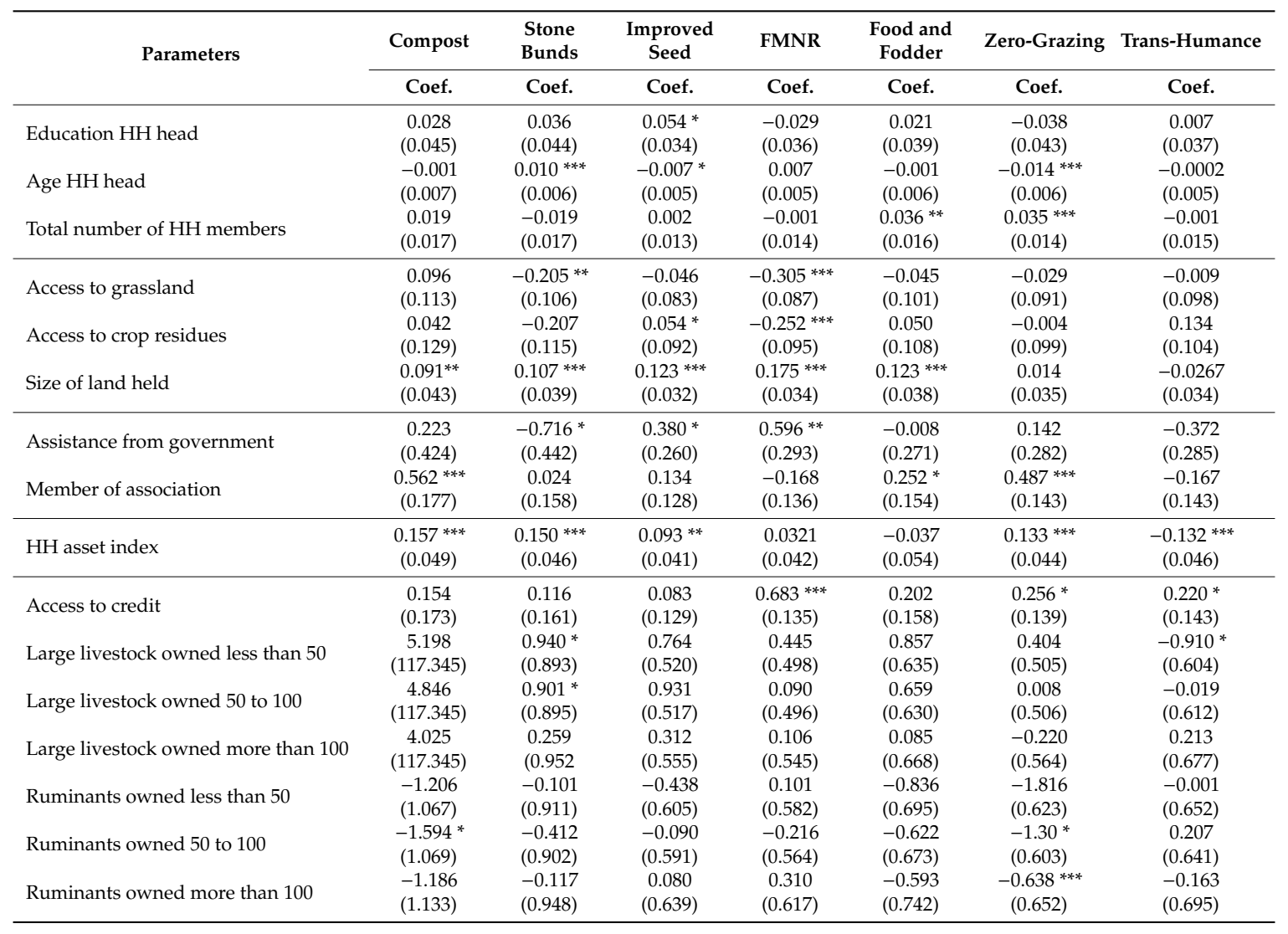


Table 5. Cont.

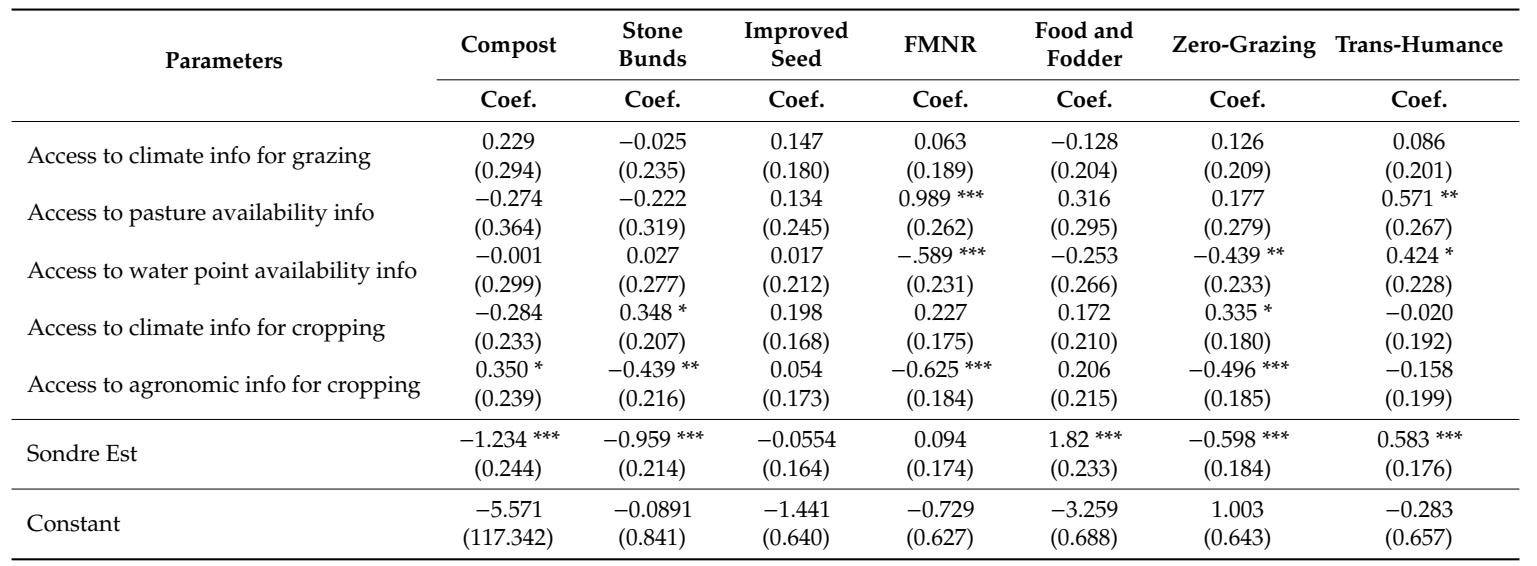

Likelihood ratio test of rho2 $1=$ rho31 $=$ rho41 $=$ rho51 $=$ rho61 $=$ rho71 $=$ rho32 $=$ rho42 $=$ rho52 $=$ rho62 $=$ rho72 $=$ rho 43 $=\operatorname{rho53}>=\operatorname{rho63}=\operatorname{rho} 73=\operatorname{rho} 54=\operatorname{rho6} 4=\operatorname{rho} 74=\operatorname{rho6} 5=\operatorname{rho} 75=\operatorname{rho} 76=0: \operatorname{chi} 2(21)=46.2754$ Prob $>$ chi2 $=0.0012$. Significance levels: $* * *, * * *$ Significant at 10,5 and $1 \%$, respectively.

Table 6. Relationships between selected determinants and engagement in adaptation options by respondent households.

\begin{tabular}{|c|c|c|c|c|c|c|c|}
\hline Parameters & Compost & $\begin{array}{l}\text { Stone } \\
\text { Bunds }\end{array}$ & $\begin{array}{l}\text { Improved } \\
\text { Seed }\end{array}$ & FMNR & $\begin{array}{l}\text { Forage and } \\
\text { Fodder }\end{array}$ & Zero-Grazing & Trans-Humance \\
\hline HH head age & & + & - & & & - & \\
\hline Size land held & + & + & + & + & + & & \\
\hline Assistance gov. & & - & + & + & & & \\
\hline Association mem. & + & & & & + & + & \\
\hline $\mathrm{HH}$ asset index & + & + & + & & & + & - \\
\hline Access to credit & & & & + & & + & + \\
\hline Info water point & & & & - & & - & + \\
\hline Agronomic info & + & - & & - & & - & \\
\hline Location in SE & - & - & & & + & - & + \\
\hline
\end{tabular}

Note: "+" indicates a positive and " $-"$ indicates a negative relation between determinant and practice.

\section{Relation between Key Livelihood Assets and Engagement in Multiple Adaptation Practices}

In terms of human capital, all three variables included in the model, namely, the household head's age, the household head's education level and size of the household, showed a significant correlation with the engagement in at least one the adaptation practices. However, only the household head's age, a proxy for farming experience, had a significant influence on three practices, indicating that age had an influence on the adoption or non-adoption of a combination of adaptation practices. The results suggest that experienced farmers were likely to use the stone bunds technique, an endogenous practice, while age was negatively correlated with the adoption of two 'exogenous' practices, namely, the planting of improved crop varieties and livestock fattening ( $p \leq 0.05$ and $p \leq 0.10$ respectively).

Physical capital, notably ownership of household physical assets, was found to be significantly correlated with the adoption of practices that target farm intensification, including livestock fattening and the use of improved seeds, as well as engagement in farm soil fertility and water conservation measures, such as composting and stone bunds. Most of these practices require sufficient physical assets to be implemented. On the other hand, the composite physical assets variable showed a negative correlation with transhumance. These results imply that well-to-do farmers did disengaged from extensive farming systems and adopted more intensified farming practices. These results are in line with Nchemechena et al. [20], who suggest that households that own relevant physical assets, including farm equipment, good housing and that have access to key infrastructure, are likely to be wealthy and hence able to uptake adaptation options such as yield-enhancing technologies and intensive farming practices that require up-front investment. 
The size of farm land held, used as a proxy for household's access to key natural assets, was significantly correlated with engagement in five of the seven investigated adaptation practices. It was positively correlated with the adoption of composting, use of stone bunds, FMNR, use of improved crop varieties, as well as fodder and forage production. Access and ownership of productive natural assets can hence facilitate the uptake of yield-enhancing and other land-based technologies, predominantly those related to the crop production system.

Concerning social capital, membership in farmer groups or associations was positively correlated with the adoption of composting, livestock fattening, as well as fodder and forage cropping in the study. Moreover, access to government assistance was significantly and positively correlated with the adoption of improved seed varieties and FMNR, while it was negatively correlated with the adoption of stone bunds and zero-grazing practices. Several explanations for these results can be advanced. Farmer group membership, generally, is likely to increase access to information, training and knowledge on new technologies and proven effective agricultural practices. Farmer group membership also facilitates access to key inputs such as improved seeds, livestock feeds and farm equipment required for the implementation of the technologies in question. NGOs and government extension services in the study area worked through farmer groups and this offered opportunities for group members to access information and other services. Assistance from government often also facilitates access to free extension services that provide information on weather forecasts and access to new technologies or better management practices. Most external initiatives, both from the government and from NGOs, were implemented through farmer groups in Burkina Faso. The pastoral zone of Sondré-Est, as all other pastoral zones, furthermore, was managed and governed by a so-called "Comité de Gestion de la Zone pastorale", which is the umbrella institution of the zone. All external actors seeking to implement activities had to pass through this local governance institution. The promotion of fodder cropping in Sondré-Est, supported by the local NGO PASMEP, for instance, was done through farmer groups after being approved by the "Comité de Gestion". Consequently, the members of each farmer group had access to inputs such as seeds, equipment and storage infrastructure. These results are in line with findings that indicate that households' social capital plays an important role in the adoption of adaptive strategies in the context of climate change as information exchange and institutional support are key to absorb and recover from losses due to climate change damages $[18,20]$.

Financial capital: Access to credit was correlated with the adoption of transhumance, livestock fattening and FMNR in the study. As shown by numerous other studies, financial capital in terms of cash disposal plays an important role in the adoption of adaptation strategies because cash, higher income and wealth enable households to absorb and recover from losses due to climate changes and hazards $[20,25]$.

Relationship between Access to Relevant Climate and Resource Availability Information and Engagement in Adaption Practices

Beyond the discussed interaction between different asset variables and engagement in the selected adaptation practices, access to agronomic information and information on water availability were found to positively and significantly affect the production and use of compost, but to negatively affect the adoption of stone bunds, FMNR and zero-grazing practices. Agronomic information associated with weather forecasts provided by extension services is important for farmers' decision-making process to adjust their farming system and activities in the face of climate change. In recent years, NGOs and non-state actors have increased efforts to support access to weather and climate services to farmers to help them manage climatic risk in their livelihood activities and strengthen their resilience [27-29]. In Burkina Faso, in addition to the government state agency "Agence Nationale de la météorologie", which is in charge of climate information delivery, NGO-driven initiatives through private agrometeorological information providers within the BRACED Programme (Building Resilience and Adaptation to Climate Extremes and Disasters) have also started providing climate services such as seasonal forecasts to the farmers through SMS [28,30]. Different kinds of climate, natural resource 
availability and agronomic information are meant to help farmers to make informed decisions about their farming activities.

Relationship between Location in the Pastoral Zone and Uptake of Adaption Practices

Being located in the pastoral zone was significantly correlated with engagement in various adaptation practices. In that vein, residents of the pastoral zone were significantly more likely to engage in transhumance and fodder and forage cropping than residents of the surrounding villages. In contrast, composting, use of stone bunds and livestock fattening were predominantly adopted by the households located outside of the pastoral zone. This divergence in the location variable's prominence is likely to be related to the fact that the zone was primarily created to provide a secure infrastructure for livestock production and that most of the residents were pastoralists whose main livelihoods remained focussed on livestock rearing, while small-scale crop production was pursued as marginal livelihood addition. Residents of the zone were more likely to engage in adaptation practices that are directly related to livestock production.

\subsubsection{Findings' Implications for Climate Change Adaptation Upscaling Initiatives}

The findings of this study showed a significant correlation between various household assets, as well as access to agronomic and climate information and a household's location, and engagement in various climate-smart adaptation practices. However, only a few were significantly correlated with the combined uptake of or engagement in multiple adaptation practices. These findings provide insights into the factors that render the adoption of various adaptation practices, both individually and in combination, more likely for pastoral and agro-pastoral households. Adoption of composting, stone bunds, improved crop varieties and the uptake of fodder and forage production, for instance, might be more likely among households that have access to land that they deem sufficient, alongside access to key household and farm equipment, as well as access to farmer associations and agronomic information. If livestock fattening is promoted, in addition to ownership of and access to key household and farm assets, as well as access to farmer groups, access to credit may also be required. Upscaling initiatives should pay attention to those factors, since they play an important role in farmers' decisions to adopt a combination of adaptation practices in their mixed crop-livestock production systems.

\section{Conclusions and Recommendations}

This study investigated the factors that affect pastoralist and agro-pastoralist households' decisions on the adoption of multiple adaptation practices in crop and livestock production systems in the Sudano-Sahelian zone of Burkina Faso. The findings revealed that the respondents in the study area adapted to climate change and variability by adopting a combination of adaptation practices that enhance household food security and livelihoods. The MVP model estimates indicated that a number of assets, climatic and agronomic information, and a household's location correlate, either positively or negatively, with the decision of pastoralist and agro-pastoralist households to adopt various agricultural adaptation practices in the study area. Concerning household assets, variables affecting uptake of multiple adaptation practices in combination were the household head's farming experience (human asset), membership in a famer group and assistance from government (social assets), access to credit (financial asset), size of farmland (natural asset) and access to various key household and farm assets, as well as to infrastructure (physical assets). Finally, beyond household assets, access to climate and agronomic information, specifically access to information about the availability of water points and pasture, alongside access to agronomic information, also correlated with engagement in these practices. Thus, policies and specific interventions that facilitate access to climate information and knowledge through mass media, mobile or social networks will likely improve farmers' awareness of climate change and can affect positively the adoption of adaptive strategies. To ensure greater relevance, this information should be designed in a way that is tailored to the interests of pastoralist and agro-pastoralist households in terms of content, language and format. Concerning future 
research needs, participatory development and modification, implementation and evaluation of the innovative adaptation and climate-resilient practices described can improve the uptake of these options and hence inform initiatives to upscale relevant adaptation practices in the agricultural sector in sub-Saharan Africa.

Author Contributions: N.Z. is the lead author; he designed the research, collected the data, performed the data analysis and interpreted the results. He wrote the first draft of the manuscript. L.E.F. contributed to research design, result interpretation, as well as writing and editing of the draft manuscript. She also managed the LGACC project altogether. Both authors contributed to reviewing the manuscript at different stages.

Acknowledgments: We are indebted to the pastoralist and agro-pastoralist communities of Sondré-Est for their participation and support in helping us acquire the data for the realization of this research. The research was carried out in the context of the USAID-funded Local Governance and Adapting to Climate Change in Sub-Saharan Africa (LGACC) research project, implemented by the World Agroforestry Centre (ICRAF) in collaboration with the International Livestock Research Centre (ILRI) and the Institut de l'Environment et de Recherches Agricoles (INERA) in Burkina Faso. Special thanks are extended to Jeanne Y. Coulibaly for her contribution to the design of the research and data analysis.

Conflicts of Interest: The authors declare no conflict of interest.

\section{References}

1. Intergovernmental Panel on Climate Change. Impacts, Adaptation, and Vulnerability: Contribution of Working Group II to the Third Assessment Report of the Intergovernmental Panel on Climate Change; Parry, M.L., Canziani, O.F., Palutikof, J.P., van der Linden, Paul, J., Hanson, C.E., Eds.; Cambridge University Press: Cambridge, UK, 2007; p. 1000.

2. Savadogo, M.; Somda, J.; Seynou, O.; Zabré, S.; et Nianogo, A.J. Catalogue des Bonnes Pratiques D'adaptation aux Risques Climatiques au Burkina Faso; UICN Burkina Faso: Ouagadougou, Burkina Faso, 2011; p. 52.

3. CILSS. Bonnes Pratiques Agro-Sylvo-Pastorales D'amélioration Durable de la Fertilité des Sols au Burkina Faso; CILSS: Ouagadougou, Burkina Faso, 2012; p. 194.

4. Barbier, B.; Yacouba, H.; Karambiri, H.; Zorome, M.; Some, B. Human vulnerability to climate variability in the Sahel: farmers' adaptation strategies in northern Burkina Faso. Environ. Manag. 2009, 43, 790-803. [CrossRef]

5. Mertz, O.; Mbow, C.; Reenberg, A.; Genesio, L.; Lambin, E.F.; D’Haen, S.; Zorom, M.; Rasmussen, K.; Diallo, D.; Barbier, B.; et al. Adaptation strategies and climate vulnerability in the Sudano-Sahelian region of West Africa. Atmos. Sci. Lett. 2011, 12, 104-108. [CrossRef]

6. Zougmoré, R.; Mando, A.; Stroosnijder, L. Economic benefits of combining soil and water conservation measures with nutrient management in semiarid Burkina Faso. Nutr. Cycl. Agroecosyst. 2005, 70, $261-269$. [CrossRef]

7. Asfaw, S.; McCarthy, N.; Lipper, L.; Arslan, A.; Cattaneo, A.; Kachulu, M. Climate Variability, Adaptation Strategies and Food Security in Malawi; ESA Working Paper No. 14-08; FAO: Rome, Italy, 2014.

8. Adger, W.N.; Agrawala, S.; Mirza, M.M.Q.; Conde, C.; O’Brien, K.; Pulhin, J.; Pulwarty, R.; Smit, B.; Takahashi, K. Assessment of adaptation practices, options, constraints and capacity. Climate Change 2007: Impacts, Adaptation and Vulnerability. In Contribution of Working Group II to the Fourth Assessment Report of the Intergovernmental Panel on Climate Change; Cambridge University Press: Cambridge, UK, 2007.

9. Scoones, I. Sustainable Rural Livelihoods: A Framework for Analysis; Working Paper 72, IDS; University of Sussex: Brighton, UK, 1998.

10. Ahmed, M.H. Climate change adaptation strategies of maize producers of the Central Rift Valley of Ethiopia. J. Agric. Rural Dev. Trop. Subtrop. 2016, 117, 175-186.

11. Deressa, T.D.; Hassan, R.M.; Ringler, C.; Alemu, T.; Yesuf, M. Determinants of farmers' choice of adaptation methods to climate change in the Nile Basin of Ethiopia. Glob. Environ. Chang. 2009, 19, 248-255. [CrossRef]

12. Ouédraogo, M.; Dembélé, Y.; Somé, L. Perceptions et stratégies d'adaptation aux changements des précipitations: Cas des paysans du Burkina Faso. Sci. Chang. Planétaires Sécheresse 2010, 21, 87-96.

13. Zampaligré, N.; Dossa, H.L.G.; Schlecht, E. Climate change and variability: Perception and adaptation strategies of pastoralists and agro-pastoralists across different zones of Burkina Faso. Reg. Environ. Chang. 2013, 14, 769-783. [CrossRef] 
14. Coulibaly, J.Y.; Mbow, C.; Silésie, W.B.; Beedy, T.; Kundhlande, G.; Musau, J. Mapping Vulnerability to Climate Change in Malawi: Spatial and Social Differentiation in the Shire River Basin American. Am. J. Clim. Chang. 2015, 4, 282-294. [CrossRef]

15. Tiemtoré, S. La Sécurisation Foncière de L'élevage dans les Zones Pastorales du Burkina Faso: Cas de Sondré Est. Mémoire de Fin de Cycle Pour L'obtention du Diplôme de Formation Supérieure en Planification Régionale et Aménagement du Territoire; Institut Panafricain Pour le Développement: Ouagadougou, Burkina Faso, 1997; p. 104.

16. Kassie, B.T.; Hengsdijk, H.; Rotter, R.; Kahiluoto, H.; Asseng, S.; Van Ittersum, M. Adapting to climate variability and change: experiences from cereal based farming in the central Rift and Kobo valleys. Ethiopia Environ. Manag. 2013, 52, 1115-1131. [CrossRef] [PubMed]

17. Kassie, M.; Pender, J.; Yesuf, M.; Kohlin, G.; Bluffstone, R.A.; Mulugeta, E. Estimating returns to soil conservation adoption in the northern Ethiopian highlands. Agric. Econ. 2008, 38, 213-232. [CrossRef]

18. Adimassu, Z.; Kessler, A. Factors affecting farmers' coping and adaptation strategies to perceived trends of declining rainfall and crop productivity in the central Rift valley of Ethiopia. Environ. Syst. Res. 2016, 5, 13. [CrossRef]

19. Apata, T.G. Factors influencing the perception and choice of adaptation measures to climate change among farmers in Nigeria. Evidence from farm households in Southwest Nigeria. Environ. Econ. 2011, 2, 74-83.

20. Nchemachena, C.; Hassan, R.; Chakwizira, J. Analysis of farm level adaptation measures to climate change in southern Africa. J. Dev. Agric. Econ. 2014, 6, 232-241.

21. Kima, S.A.; Okhimamhe, A.A.; Kiema, A.; Zampaligré, N.; Sule, I. Adapting to the impacts of climate change in the sub-humid zone of Burkina Faso, West Africa: Perception of agro-pastoralists. Pastor. Res. Policy Pract. 2015, 5, 16. [CrossRef]

22. Fuchs, L.E.; Njuguna, L.W. Characterizing Local Capacities: A Decision-Support Framework for Adaptive Capacity Assessment and Climate Change Adaptation Planning; Manual, LGACC Project Document No. 2; ICRAF: Nairobi, Kenya, 2019.

23. Zougmoré, R.; Jalloh, A.; Tioro, A. Climate-smart soil water and nutrient management options in semiarid West Africa: A review of evidence and analysis of stone bunds and zaï techniques. Agric. Food Secur. 2014, 3, 16. [CrossRef]

24. Cunningham, P.; Tougiani, A. Reforesting the Sahel: Farmer Managed Natural Regeneration. Domestication des Espèces Agroforestières au Sahel: Situation Actuelle et Perspectives; ICRAF Working Paper; ICRAF: Nairobi, Kenya, 2005; Volume 5.

25. Deressa, T.D.; Hassan, D.R.M.; Ringler, C. Perception of and adaptation to climate change by farmers in the Nile basin of Ethiopia. J. Agric. Sci. 2011, 149, 23-31. [CrossRef]

26. Hassan, C.; Nchemachena, C. Determinants of African farmers' strategies for adapting to climate change: Multinomial choice analysis. Afr. J. Agric. 2008, 2, 83-104.

27. Hansen, J. CCAFS Contributions to Climate Services in Africa; CCAFS Info Note; CCAFS: Frederiksberg, Denmark, 2017; p. 2.

28. Harvey, B.; Jones, L.; Cochrane, L.; Singh, R. The evolving landscape of climate services in sub-Saharan Africa: What roles have NGOs played? Clim. Chang. 2019. [CrossRef]

29. ICCS5. Innovation in climate services and capacity building. In Proceedings of the Fifth International Conference on Climate Services, Cape Town, South Africa, 28 February-2 March 2017; p. 64.

30. Visman, E.; Audia, C.; Crowley, F.; Ilboudo, J.; Sanou, P.; Henley, E.; Malick, V.; Ritchie, A.; Fox, G.; Traore, M.; et al. Developing Decision-Relevant Climate Information and Supporting Its Appropriate Application; Learning Paper \#6, for the Christian Aid-led BRACED Consortia; King's College London: London, UK, 2017; p. 12.

(C) 2019 by the authors. Licensee MDPI, Basel, Switzerland. This article is an open access article distributed under the terms and conditions of the Creative Commons Attribution (CC BY) license (http://creativecommons.org/licenses/by/4.0/). 